\title{
MICROSURGICAL LANDMARKS IN MINIMALLY INVASIVE TRANSFORAMINAL LUMBAR INTERBODY FUSION
}

\author{
REFERÊNCIAS MICROCIRÚRGICAS EM FUSÃO INTERSOMÁTICA LOMBAR \\ TRANSFORAMINAL MINIMAMENTE INVASIVA
}

\section{REFERENCIAS MICROQUIRÚRGICAS EN LA FUSIÓN INTERSOMÁTICA LUMBAR TRANSFORAMINAL DE MÍNIMA INVASIÓN}

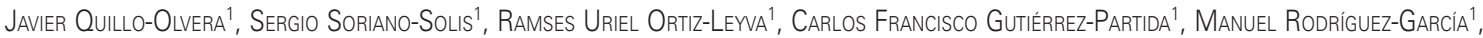 \\ José ANTONIO SORIANO-SÁnCHEZ ${ }^{1}$
}

\begin{abstract}
Microsurgical landmarks of the facet joint complex were defined to provide guidance and security within the tubular retractor during transforaminal surgery. A retrospective observational study was performed in segments L4-L5 by the left side approach. Microsurgical relevant photos, anatomical models and drawing were used to expose the suggested landmarks. The MI-TLIF technique has advantages compared with conventional open TLIF technique, however minimally invasive technique implies lack of security for the surgeon due to the lack of defined microanatomical landmarks compared to open spine surgery, and disorientation within the tubular retractor, the reason why to have precise microsurgical references and its recognition within the surgical field provide speed and safety when performing minimally invasive technique.
\end{abstract}

Keywords: Spinal fusion; Arthrodesis; Lumbar vertebrae; Anatomic landmarks.

\section{RESUMO}

Foram definidas referências anatômicas microcirúrgicas do complexo facetário para obter orientação e segurança no interior do retrator tubular durante a cirurgia transforaminal. Realizou-se um estudo observacional retrospectivo dos procedimentos MI-TLIF nos segmentos L4-L5 com acesso lateral esquerdo. Foram empregados fotos microcirúrgicas relevantes, modelo anatômico e esquemas para expor as referências sugeridas. A técnica de MI-TLIF tem vantagens quando comparada com a técnica TLIF a céu aberto convencional, no entanto, a técnica minimamente invasiva implica falta de segurança para o cirurgião, devido à ausência de referências microanatômicas definidas em comparação com a cirurgia a céu aberto, além de falta de orientação no interior do retrator tubular. Por isso, ter referências microcirúrgicas precisas e seu reconhecimento dentro do campo cirúrgico proporciona rapidez e segurança ao realizar a técnica minimamente invasiva.

Descritores: Fusão vertebral; Artrodese; Vértebras lombares; Pontos de referência anatômicos.

\section{RESUMEN}

Se definieron las referencias anatómicas microquirúrgicas del complejo facetario para aportar orientación y seguridad dentro del portal tubular durante la cirugía transforaminal. Se realizó un estudio observacional retrospectivo de procedimientos MI-TLIF en segmentos L4-L5 abordados del lado izquierdo. Se utilizaron fotos microquirúrgicas relevantes, modelo anatómico y esquemas para exponer las referencias anatómicas sugeridas. La técnica de MI-TLIF tiene ventajas comparada con la técnica abierta convencional de TLIF, sin embargo la técnica mínimamente invasiva confiere falta de seguridad para el cirujano debido a la carencia de referencias microanatómicas definidas comparado con la cirugía abierta y desorientación dentro del acceso tubular por lo que tener referencias microquirúrgicas precisas y su reconocimiento dentro del campo quirúrgico aportan rapidez y seguridad al realizar la técnica mínimamente invasiva.

Descriptores: Fusión vertebral; Artrodesis; Vértebras lumbares; Puntos anatómicos de referencia.

\section{INTRODUCTION}

In 1982, Harms and Rolinger suggested placing bone graft and titanium mesh in the intersomatic space, with distraction using prior transpedicular instrumentation through the direct transforaminal route; this approach could be completed by exposing the ipsilateral foramen, with minimal retraction of the thecal sac. The approach was called transforaminal lumbar interbody fusion (TLIF) and offers an alternative to posterior lumbar interbody fusion (PLIF), with the intention of achieving a circumferential fusion with minimal risk to the neural structures and avoiding the need for two separate surgical procedures. ${ }^{1-3}$ Minimally invasive TLIF (MI-TLIF) was described for the first time by Foley et al, in 2003. ${ }^{4}$ This approach is less traumatic; it has more rapid recovery compared with conventional open TLIF, and the more lateral exposure of the intersomatic space allows less manipulation of neural elements, preserves the posterior tension band, and reduces injury to the paraspinal muscles. ${ }^{1,2,5,6}$ The indications of MI-TLIF are: refractory mechanical low back pain, radicular pain associated with spondylolisthesis grade 1 and 2, degenerative disc disease, and recurrent disc herniation. 1,4,5 However a weakness of the technique is the lack of microanatomical orientation, because the standard anatomical landmarks are not visible and it is technically difficult to work through a small surgical access incision. ${ }^{1}$ The perioperative time is longer than for conventional open TLIF, and exposure to radiation during surgery is higher. ${ }^{2}$ The aim of this work was to define the most relevant microanatomical landmarks of microsurgical target in the MI-TLIF; facet joint complex.

1. Instituto Soriano de Cirugía de Columna Mínimamente Invasiva, Distrito Federal, Mexico. 


\section{MATERIAL AND METHODS}

We carried out an observational study during MI-TLIF procedures; L4-L5 intersomatic left side levels were photographed under a microscope and edited in the OSX program (1983-2015, Apple Inc.). We then compared these with diagrams and anatomical models in order to show the microsurgical landmarks used by the Senior author (JASS) for access to the lumbar interbody space through the foramen during the MI-TLIF technique. All the surgeries were performed by the Senior author (JASS), assisted by the Principal author (JQO). The study was approved by the Soriano Institute of Minimally Invasive Spine Surgery (JQO012015ISCCMI)

\section{PROCEDURE}

The patient was placed in the prone position on a radiolucent operating table. Conventional fluoroscopy was performed to locate the radiological landmarks in MI-TLIF, in order to make the incision and accesses for placement of the percutaneous pedicle screws. We then started performing true shots with the C-arm. Working by the anteroposterior route, the upper endplate of the adjacent vertebral body and the upper endplate of the underlying vertebral body of the segment to be fused must be aligned, and in a true lateral shot with the C-arm, the surgical vector of the approach will be the intersomatic space (L4-L5, in this case). We then performed a longitudinal incision in the skin between 1.7 to $2 \mathrm{~cm}$ in most cases, dissecting the subcutaneous tissue, thoracolumbar fascia, subfascicular tissue and common muscle fascia by planes, until the boundary between the longissimus and iliocostalis muscles was visualized. Subsequently, blunt dissection was done, using the index finger to feel and identify the facet joint (L4-L5 left, in this case). The tubular retractors were then placed progressively, until the last retractor was positioned and fixed to the surgical table.

Then microscopic stage then began, with the aim of performing the transforaminal decompression, preparing the interbody space, and inserting the bone graft and interbody cage.

\section{MICROSURGICAL LANDMARKS}

The first microscopic image that we see through the tubular retractor is the remains of adjacent tissue to the facet joint; these can be easily coagulated and removed with disc forceps. We must subsequently define the limits of drilling, which will enable us to access the foramen from an angled posterolateral tubular approach. The upper microsurgical limit is the apex of the superior articular process; which is the most cephalic point of the superior articular process of the underlying vertebral body of the segment to be fused. The lower limit is the transverse-facet junction, which is at the same height as the inferior pedicle of the segment to be fused. Its intraoperative recognition is critical to avoid transgressing the upper limit of the inferior pedicle where will the inferior screw will be inserted. (Figure 1) The medial limit of the microsurgical transforaminal access is the articular cleft, which it is generally visible when the adjacent facet joint tissue is removed. (Figures 2 and 3) Having located the three microanatomical landmarks, it is completed by drilling the lateral facetectomy of the segment to be fused, to reach the intervertebral disc safely and perform microdiscectomy, with preparation of the endplate, and pla-

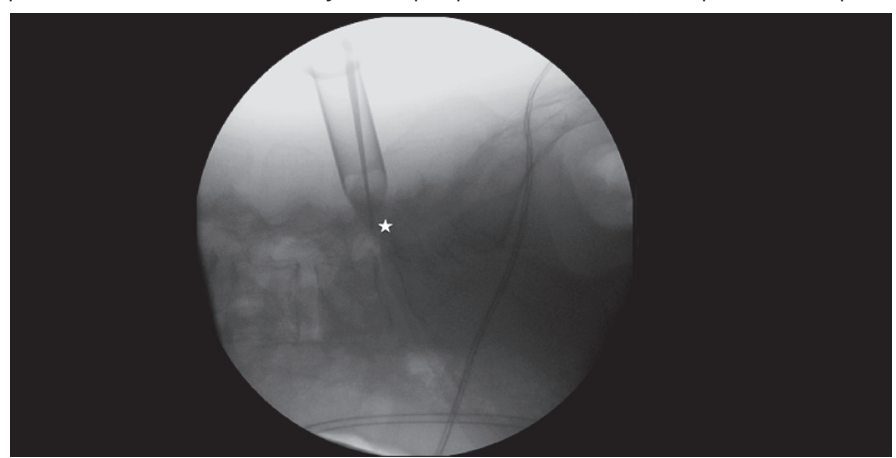

Figure 1. White star in the transverse-facet junction. cement of bone graft and intersomatic cage. Finally, the percutaneous pedicle screws and rod are inserted, correcting the lordosis if required.

\section{DISCUSSION}

In 1982 Harms and Rolinger developed the open technique of transforaminal lumbar interbody fusion as an alternative to PLIF. Foley et al., in 2003, described a minimally invasive technique for performing the same approach. 1,2,4,6 However the technique has progressed at the same time of technological developments, and has advantages such as fusion of the three spinal segments, better visualization of the lateral interbody space, and the ability to prepare the intervertebral space through a unilateral approach, with less retraction of the thecal sac, preserving the posterior tension band and ensuring minimal paraspinal muscle transgression. Comparing the length of hospital stay, intraoperative bleeding, and perioperative use of narcotics between the MI-TLIF versus conventional open TLIF, the first has better results. The MI-TLIF is more cost-effective compared to open TLIF in the long term. The fusion rate at one year is similar for both techniques. ${ }^{1,2,5,6}$

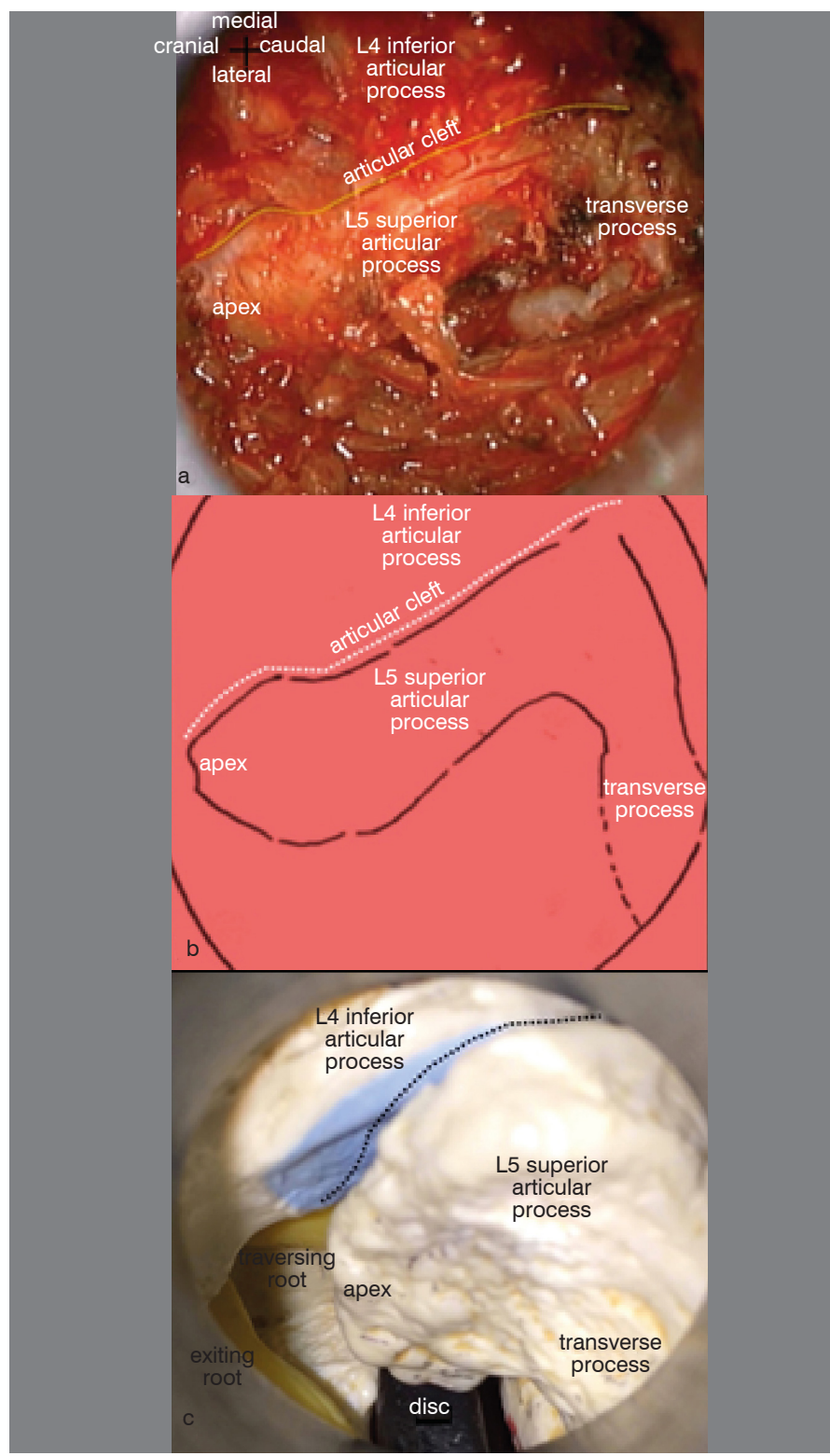

Figure 2. a) Three landmarks were exposed in the surgical field: apex of left L5 superior articular process superiorly, the articular cleft medially and transverse-facet junction inferiorly. b) Diagram illustrating the landmarks described c) View through the tubular retractor on an anatomical model, the neural structures are observed: exiting root and traversing root and below both the intervertebral disc. 


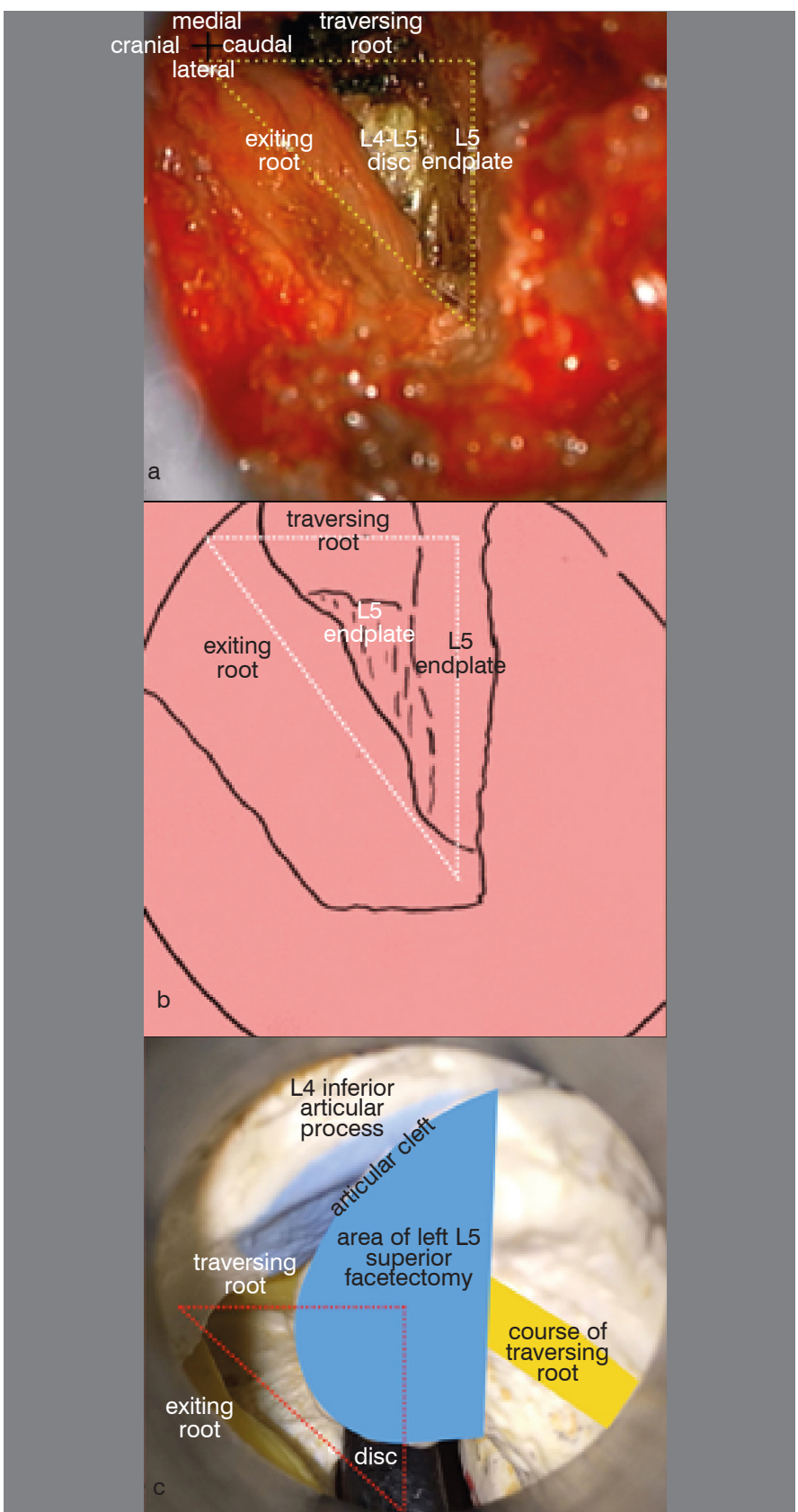

Figure 3. a) Surgical photo after drilling left articular process of L5. The traversing root and exiting root are observed medially and laterally in surgical field. b) The intervertebral disc is reached through the Kambin's triangle; limited by a medial cathetus: a traversing root, a lower cathetus: L5 endplate, and a hypotenuse: exiting root. c) View through the tubular retractor on an anatomical model. Blue: drilling area in the L5 lateral facet. Yellow: neural elements. Safe access to the intervertebral disc through Kambin's triangle (red dotted triangle), which is accessed when the proposal landmarks are observed.

\section{REFERENCES}

1. Lau D, Lee JG, Han SJ, Lu DC, Chou D. Complications and perioperative factors associated with learning the technique of minimally invasive transforaminal lumbar interbody fusion (TLIF). J Clin Neurosci. 2011:18(5):624-7.

2. Talia AJ, Wong ML, Lau HC, Kaye AH. Comparison of the different surgical approaches for lumbar interbody fusion. J Clin Neurosci. 2015;22(2):243-51.

3. RosenbergWS, Mummaneni PV. Transforaminal lumbar interbody fusion: technique, complications, and early results. Neurosurgery. 2001:48(3):569-74.

4. Holly LT, Schwender JD, Rouben DP, Foley KT. Minimally invasive transforaminal lumbar interbody fusion: indications, technique, and complications. Neurosurg Focus. 2006;20(3):E6.

5. Moskowitz A. Transforaminal lumbar interbody fusion. Orthop Clin North Am. 2002;33(2):359-66

6. Wong AP, Smith ZA, Stadler JA 3rd, Hu XY, Yan JZ, Li XF, et al. Minimally invasive transfo-
Indications for MI-TLIF are: refractory mechanical low back pain, radicular pain associated with spondylolisthesis grades 1 and 2, degenerative disc disease, and recurrent disc herniation. ${ }^{1,4,5}$ The disadvantages of MI-TLIF are: longer surgery times, and higher exposure to radiation during surgery. ${ }^{2}$ Complications of MI-TLIF are: cerebrospinal fluid fistula, surgery on the wrong level, breakage of the Kirschner wire or Jamshidi needle, improper placement of pedicle screws, and pseudoarthrosis. ${ }^{6}$ Contraindications of TLIF are: severe intersomatic collapse, and the formation of circumferential intersomatic osteophytes; cases where distraction of the intervertebral space is risky, and significant epidural scarring during revision surgery. ${ }^{2}$ The anatomical basis for a minimally invasive approach is the preservation of the muscular plane to create a surgical channel to work with, and reduce postoperative muscle denervation and weakness. ${ }^{7}$ The surgical landmarks described in this paper help define a specified surgical area in a minimally invasive procedure to achieve secure access to the target of the approach. Most current papers mention a disadvantage of the MI-TLIF technique, which is inconsistency in microsurgical anatomical landmarks compared to open surgery. Systematic and standardized use of the references described above inspires confidence during surgery and enables orientation within the tubular retractor. Secure access to the foramen is achieved when drilling the upper facet and entering the secure area within Kambin's triangle, bounded by two catheti and a hypotenuse; the medial cathetus is the dural sac and traversing root, the lower cathetus is the intervertebral disc, and the hypotenuse is the exit root of the segment to be fused. ${ }^{8}$ The drilling of the upper facet is combined with the laterality and angulation of tubular access, minimizing the drilling of the medial posterior arch. Minimally invasive techniques have been limited due to insufficient exposure area compared to open surgery of the spine, a situation that becomes less important when there is a specific and defined surgical target, as proposed in this work. ${ }^{9}$ The reasons why young spine surgeons often choose conventional open TLIF over MI-TLIF are: (1) a long learning curve, (2) prolonged surgical time compared to open surgery, (3) the difficulty of managing bilateral symptoms using a unilateral approach, and (4) the fact that MI-TLIF involves longer radiation exposure than conventional lumbar fusion. However there are numerous reasons to choose MI-TLIF over conventional open TLIF: shorter recovery times and return to normal activity, cosmetic improvement, decreased postoperative pain, decreased hospitalization times, reduced dependence on postoperative pain relief, and less intraoperative bleeding. ${ }^{10}$ In addition, pathological changes in the paraspinal muscles after open surgery are well documented, and have been associated with poor outcome. ${ }^{10}$

\section{CONCLUSIONS}

MI-TLIF is a technical challenge, especially during the time the surgeon takes to become familiar with the technique. This approach requires deep knowledge of microanatomy and microsurgery, and has long learning curve. The microsurgical landmarks proposed in this paper provide guidance and security when entering the foramen during the microscopic stage of MI-TLIF.

All authors declare no potential conflict of interest concerning this article. raminal lumbar interbody fusion (MI-TLIF): surgical technique, long-term 4-year prospective outcomes, and complications compared with an open TLIF cohort. Neurosurg Clin N Am. 2014:25(2):279-304.

7. Elboghdady IM, Naqvi A, Jorgenson AY, Marquez-Lara A, Singh K. Minimally invasive transforaminal lumbar interbody fusion for lumbar spondylolisthesis. Ann Transl Med. 2014;2(10):99.

8. Park KD, Lee JH, ParkY. Injectate Volumes Needed to Reach Specific Landmarks and Contrast Pattern in Kambin's Triangle Approach with Spinal Stenosis. Ann Rehabil Med. 2012;36(4):480-7. 9. Ozgur BM, Yoo K, Rodriguez G, Taylor WR. Minimally-invasive technique for transforaminal lumbar interbody fusion (TLIF). Eur Spine J. 2005;14(9):887-94.

10. Scuderia GR, Tria AJ, editors. Minimally invasive surgery in orthopedics. New York: Springer Science Business Media; 2010. p. 569-77. 